\title{
Vitamins, Flavonoids, and Phenolic Acid Levels in Early- and Late-ripening Apricot (Prunus armeniaca L.) Cultivars from Turkey
}

\author{
Muttalip Gündoğdu' \\ Yüzüncü Yll University, Agriculture Faculty, Department of Biotechnology, \\ Van, Turkey \\ Tuncay Kan \\ İnönü University, Agriculture Faculty, Horticulture Department, Malatya, \\ Turkey \\ Mustafa Kenan Gecer \\ Iğdır University, Agriculture Faculty, Horticulture Department, I $\breve{g} d ı r$, Turkey
}

Additional index words. apricot, diversity, phytochemicals, ripening, HPLC

\begin{abstract}
This study aimed at determination of vitamin (A, E, C, $\beta$-carotene, and lycopene), phenolic, and flavonoid contents in apricots at different stages of ripening using high-performance liquid chromatography (HPLC). The effect of ripening in terms of phytochemical contents was investigated. Early period apricots showed 2.5 to three times higher level of vitamins (A, E, C, and $\beta$-carotene, and lycopene) in all types of apricots than others $(P<0.05)$. Early-ripened cultivar, Boccuia, showed the highest level of vitamins, although a higher level of vitamin $C$ was measured in late-ripened cultivar Levent $(P<0.05)$. No lycopenes were determined in late-period apricots in contrary to early- and middle-period apricots. Levels of phenolics and flavonoids were measured in all types (3-B-Q-D, procyanidin B1, B2, B3, caffeic acid, gallic acid, p-coumaric acid, epigallocatechine, catechine, epictechine, chlorogenic acid, ferrulic acid, and routine) and statistical deviation of all types was noted $(P<0.05)$. Among all, the cultivar Özal showed the highest level of chlorogenic acid $\left(45,843.00 \mu \mathrm{g} \cdot \mathrm{g}^{-1} \mathrm{dry}\right.$ matter) in all ripening periods, where middle-ripened cultivar Adilcevaz showed the lowest level of p-coumaric acid (7.93 $\mu \mathrm{g} \cdot \mathrm{g}^{-1}$ dry matter content base).
\end{abstract}

Phenolic compounds are important components of many fruits, vegetables, and beverages, in which they contribute to color and sensory properties such as bitterness and astringency (Macheix et al., 1990). Consumption of foods and beverages rich in phenolic content is found to be correlated with reduced incidences of heart diseases in epidemiological studies (Criqui and Ringel, 1994; Renaud and de Lorgeril, 1992).

The anticarcinogenic and antioxidant properties of vitamins A, C, E, $\beta$-carotene, and the essential element selenium are relatively recently discovered. Independently or in combination, vitamins $\mathrm{C}, \mathrm{E}$, selenium, and carotenoids may act as anticancer or cardioprotective agents by a variety of mechanisms. One such protective mechanism, attributed to vitamin $\mathrm{C}$ and $\mathrm{E}$ and the carotenoids, is antioxidant (radical-scavenging) activity (RiceEvans et al., 1997). Vitamin C is known as the most important vitamin in fruits and vegetables for human nutrition (Lee and Kader, 2000).

Received for publication 28 Feb. 2013. Accepted for publication 3 Apr. 2013.

${ }^{1}$ To whom reprint requests should be addressed; e-mail gundogdu_m@hotmail.com. apricots. The other phenolic compounds determined in apricots are neochlorogenic acid, caffeic acid, p-coumaric acid, ferulic acid, and their esters. (+)-Catechin and (-)-epicatechin are also determined in apricot fruits and their products (Arts and van de Putte, 2000; Dragovic-Uzelac et al., 2005a; Garcia-Viguera et al., 1997; Radi et al., 1997; Rish and Herrmann Die Gehalte, 1988). Flavonols in apricots occur mostly as glucosides and rutinosides of quercetin and of kaempferol; however, quercetin 3-rutinoside (rutin) predominates (Dragovic-Uzelac et al., 2005b; Garcia-Viguera et al., 1997; Henning and Herrmann, 1980). Apricot fruits contain different levels of phytochemicals such as vitamins, carotenoids, and polyphenols, which are the determinants of taste, color, and nutritive values (Gardner et al., 2000; Rice-Evans et al., 1997; Vinson et al., 1998).

The carotenoids are the most widespread group of pigments in nature, and they are present in all photosynthetic organisms and are responsible for most of yellow to red colors of fruits and flowers. Ripening of the fruits involves series of complex biochemical reactions, which lead to production of phenolic compounds, carotenoids, and formation of volatile compounds (Speirs and Brady, 1991). Phenolic compounds generate a sourish taste in fruit products and blurred appearance in fruit juices (Cemeroğlu et al., 2004; Gündogdu et al., 2011). Differences may ocur in content and quantities of phytochemicals, which depend on a number of factors such as sunlight, soils, season, region of cultivation, fruit variety, and ripening stage (Harris, 1977; Spanos and Wrolstad, 1992). This study aims to analyze and describe the differences in terms of vitamin (A, E, C, carotene, and lycopene), phenolics, and flavonoid contents by HPLC. This study demonstrates once again that apricots are highly healthy food products resulting from their chemical contents. More detailed knowledge on the variability in nutrient contents of the cultivars will be of benefit in future selection of apricot genotypes with improved nutritional quality and processing characteristics.

\section{Materials and Methods} regions within the same variety (Erdoğan and Erdemoğlu, 2011; Munzuroglu et al., 2003). Research on other plant species indicated that level of carotenoids varies significantly according to the stage of ripening. During ripening of tomato fruit, there is a remarkable accumulation of carotenoids of which lycopene represents $\approx 90 \%$ of the total (Fraser et al., 1994). In acerola fruits (Malpighia emarginata D.C.), carotenoid content was higher in mature fruits (Lima et al., 2005).

Despite apricot widely grown in many parts of the world, the Malatya region located in eastern Turkey is particularly important for apricot production and processing as a result of its favorable climatic and geographical conditions (Altindag et al., 2006; Ercisli, 2009). The apricot varieties contain different levels of polyphenols as summarized by Macheix et al. (1990). Chlorogenic acid (5-caffeoylquinic acid) is the dominant phenolic compound in

\section{Plant material}

Cultivars (Boccucia, C.D. Rona, Tyrinte, Aprikoz) and genotypes (Dortyol-4, Adilcevaz, Ordubat, Ziraat Okulu, Geç Aprikoz, Levent, Özal) were used in the study, which are grown in the Malatya Fruit Research Institute $\mathrm{Na}$ tional Apricot Genetics Resources Plot. The types and cultivar (Prunus armeniaca L.) used in all of the experiments were fresh apricots harvested. Fruits were harvested at deep orange 1 (fully ripe) in Malatya, Turkey (Table 1). At each harvest date, we formed random lots, each with 30 fruits. Immediately after picking, fruits were cut into small pieces, frozen in liquid nitrogen, and stored at $-80^{\circ} \mathrm{C}$ for subsequent analysis. Fruits used for polyphenol and vitamin isolation and characterization were harvested at the deep orange 1 (fully ripe) stage. The apricot types used in 
Table 1. Meteorological data for harvest dates of early-, middle-, and late-period apricot types and cultivar.

\begin{tabular}{lrcccccc}
\hline $\begin{array}{l}\text { Types and } \\
\text { cultivars }\end{array}$ & $\begin{array}{r}\text { Date of } \\
\text { harvest }\end{array}$ & $\begin{array}{c}\text { Avg temp. } \\
\left({ }^{\circ} \mathrm{C}\right)\end{array}$ & $\begin{array}{c}\text { Total } \\
\text { rainfall } \\
(\mathrm{mm})\end{array}$ & $\begin{array}{c}\text { Antinoğraf } \\
\text { sun values } \\
\left(\mathrm{CAL} / \mathrm{cm}^{2} / \mathrm{min}\right)\end{array}$ & $\begin{array}{c}\text { Avg relative } \\
\text { humidity }(\%)\end{array}$ & $\begin{array}{c}\text { Avg } \\
\text { minimum } \\
\text { temp. }\left({ }^{\circ} \mathrm{C}\right)\end{array}$ & $\begin{array}{c}\text { Avg } \\
\text { maximum } \\
\text { temp. }\left({ }^{\circ} \mathrm{C}\right)\end{array}$ \\
\hline Boccucia & 9 June & 25.3 & 4.0 & 575.30 & 35.8 & 17.9 & 32.3 \\
C.D. Rona & 23 June & 26.7 & 4.0 & 575.30 & 35.8 & 17.9 & 32.3 \\
Tyrinte & 24 June & 25.7 & 4.0 & 575.30 & 35.8 & 17.9 & 32.3 \\
Dortyol-4 & 30 June & 26.1 & 4.0 & 575.30 & 35.8 & 17.9 & 32.3 \\
Ordubat & 15 July & 26.8 & 5.8 & 568.88 & 37.6 & 20.3 & 33.6 \\
Adilcevaz & 9 July & 25.7 & 5.8 & 568.88 & 37.6 & 20.3 & 33.6 \\
Ziraat okulu & 1 July & 25.7 & 5.8 & 568.88 & 37.6 & 20.3 & 33.6 \\
Aprikoz & 25 July & 21.7 & 39.0 & 451.83 & 42.8 & 14.8 & 27.1 \\
Gec Aprikoz & 19 Sept. & 20.7 & 39.0 & 451.83 & 42.8 & 14.8 & 27.1 \\
Ozal & 1 Sept. & 20.7 & 39.0 & 451.83 & 42.8 & 14.8 & 27.1 \\
Levent & 7 Sept. & 21.03 & 39.0 & 451.83 & 42.8 & 14.8 & 27.1 \\
\hline
\end{tabular}

the study were taken from Malatya Fruit Research Institute National Apricot Genetics Resources Plot and all trees have been subjected to identical agricultural procedures (irrigation, fertilization, spraying, soil). Taking also these factors into consideration, the study aimed to explore the effects of sun light on vitamin A, E, C, $\beta$-carotene, and lycopene levels in fresh fruits of apricots at different ripening stages. Sunlight, in general, is an important determinant of vitamin $\mathrm{A}, \beta$-carotene, and lycopene levels.

\section{Chemicals}

3-B-Q-D, procyanidin $B 1, B 2, B 3$, caffeic acid, gallic acid, p-coumaric acid, epigalloctaechine, catechin, epicatechin, chlorogenic acid, ferrulic acid, and quercetin-3, rutinoside (rutin). Chlorogenic and p-coumaric acid were obtained from Fluka (Neu-Ulm, Germany); (+)-catechin, (-)-epicatechin, quercetin-3, rutinoside (rutin), ferulic acid, vitamin $\mathrm{A}, \mathrm{E}, \mathrm{C}, \beta$-carotene, and lycopene were obtained from Sigma (Deisenhofen, Germany); caffeic acid was obtained from Merck (Darmstadt, Germany). HPLC-grade ethanol, methanol, acetonitrile chloroform, acetone, n-hexane, acetic acid chemical Co 1, 2-dichloroethane, anhydrous sodium sulphate, tertbutylhydroquinone ( $t \mathrm{BHQ})$, and perchloric acid were from Merck.

\section{Extraction and determination of phenolic acids and flavonoids}

The polyphenols in examined samples were extracted using a procedure described by Dragovic-Uzelac et al. (2005a) based on the method of Bengoechea et al. (2007). Each apricot fruit puree $(50 \mathrm{~g})$ was mixed with $50 \mathrm{~mL}$ methanol/ $\mathrm{HCl}(100: 1, \mathrm{v} / \mathrm{v})$, which contained $2 \% t \mathrm{BHQ}$ in an inert atmosphere (N) during $14 \mathrm{~h}$ at $35{ }^{\circ} \mathrm{C}$ in the dark. The extract was then centrifuged at $5000 \mathrm{rpm} / \mathrm{min}$. Supernatant were evaporated to dryness under reduced pressure $\left(35\right.$ to $\left.40{ }^{\circ} \mathrm{C}\right)$. The residue was dissolved in $25 \mathrm{~mL}$ of water/ ethanol $(80: 20, \mathrm{v} / \mathrm{v})$ and extracted four times with $25 \mathrm{~mL}$ of ethyl acetate. The organic fractions were combined, dried for 30 to 45 min with anhydrous sodium sulphate, filtered through the Whatman No. 40 filter (Whatman International Ltd., Kent, U.K.), and evaporated to dryness under vacuum ( 35 to $40{ }^{\circ} \mathrm{C}$ ). The residue was dissolved in $1 \mathrm{~mL}$ of methanol/water $(50: 50, \mathrm{v} / \mathrm{v})$ and filtered through a $0.45-\mu \mathrm{m}$ filter (nylon membranes; Supelco Inc., Bellefonte, PA) before being injected $(20 \mu \mathrm{L})$ into the HPLC apparatus. Samples were extracted in triplicate.

Pressurized liquid extractions (PLEs) were performed on a DionexASE 200 (Dionex Corp., Sunnyvale, CA) system. The pre-set default conditions were as follows: pre-heating period, $5 \mathrm{~min}$; solvent flush volume, $60 \%$ of the extraction cell volume; number of extraction cycles, three; purge, $90 \mathrm{~s}$ using pressurized nitrogen (99.995\% of purity, $150 \mathrm{psi}$ ); and collection, in $60-\mathrm{mL}$ glass vials with Teflon-coated rubber caps (I-CHEM, New Castle, DE). The solvent used was previously degassed to avoid the oxidation of the analytes under the operating conditions. Optimum extraction conditions were determined as 1500 psi pressure, $40{ }^{\circ} \mathrm{C}$ temperatures, and 1-h application time in the PLE system. Propolis ethanol extracts $(1 \mathrm{~g})$ was mixed in gradient conditions with methanol/water/ hydrochloric acid (75:20:5), which contained $2 \% t$ BHQ in an 11- or 22-mL stainless steel extraction cell. Then, each one was filtered through a $0.45-\mu \mathrm{m}$ nylon membrane (Lida, Kenosha, WI) and transferred to a $50-\mathrm{mL}$ volumetric flask. Solvents was evaporated to dryness in a Turbovap LV Evaporator (Zymark, Hopkinton, MA) provided with a nitrogen stream in a water bath at $40{ }^{\circ} \mathrm{C}$. The residue was reconstituted in $(2 \mathrm{~mL})$ methanol-wateraqueous $(50: 50, \mathrm{v} / \mathrm{v})$ and which was brought up to its volume with methanol-water filtered through a $0.45-\mu \mathrm{m}$ polytetrafluoroethylene filter (Waters, Milford, CA) before injection into the HPLC system.

Polyphenol analysis were performed on an Agilent Series 1100 liquid chromatography, equipped with a vacuum degasser, a quaternary pump, and a Agilent $1100, \mathrm{G} 1315 \mathrm{~B}$ DAD detector, connected to HPChemStation software. A reversed-phase ACE 5 C18A11608 $(250 \times 4.6 \mathrm{~mm}, 4 \mu \mathrm{m})$ column was used. The content of solvents and used gradient elution conditions were previously described by Dragovic-Uzelac et al. (2005a). For gradient elution, mobile phase A contained 3\% acetic acid in water; solution B contained a mixture of $3 \%$ acetic acid, $25 \%$ acetonitrile, and $72 \%$ water. The following gradient was used: 0 to $40 \mathrm{~min}$, from $100 \% \mathrm{~A}$ to $30 \% \mathrm{~A}, 70 \% \mathrm{~B}$ with a flow rate $1 \mathrm{~mL} \cdot \mathrm{min}^{-1} ; 40$ to $45 \mathrm{~min}$, from
$30 \% \mathrm{~A}, 70 \%$ B to $20 \% \mathrm{~A}, 80 \%$ B with flow rate $1 \mathrm{~mL} \cdot \mathrm{min}^{-1}$; 45 to $55 \mathrm{~min}$, from $20 \% \mathrm{~A}$, $80 \% \mathrm{~B}$ to $15 \% \mathrm{~A}, 85 \% \mathrm{~B}$ with flow rate $1.2 \mathrm{~mL} \cdot \mathrm{min}^{-1}$; 55 to $57 \mathrm{~min}$, from $15 \% \mathrm{~A}$, $85 \% \mathrm{~B}$ to $10 \% \mathrm{~A}, 90 \% \mathrm{~B}$ with flow rate $1.2 \mathrm{~mL} \cdot \mathrm{min}^{-1}$; and 57 to $75 \min 10 \% \mathrm{~A}, 90 \%$ $\mathrm{B}$ with flow rate $1.2 \mathrm{~mL} \cdot \mathrm{min}^{-1}$. Operating conditions were as follows: column temperature, $30{ }^{\circ} \mathrm{C}$, injection volume, $20 \mu \mathrm{L}$, ultravioletVIS photo diode array detection at $280 \mathrm{~nm}$. Detection was performed with an ultravioletVIS photodiode array detector by scanning spectra from 210 to $360 \mathrm{~nm}$. Stock standard solutions at a concentration of $1 \mathrm{mg} \cdot \mathrm{mL}^{-1}, \mathrm{G} 1$ were prepared in methanol/water $(1: 1)$ and stored at $4{ }^{\circ} \mathrm{C}$ in darkness. Different range calibration curves for different polyphenol components in apricots samples were used.

\section{Analytical quality control}

Recoveries were measured by comparing retention times and spectral data with those of authentic standards. Quantitative determinations were carried out using calibration curves of the standards.

\section{Extraction and determination of vitamins}

Apricot samples $(50 \mathrm{~g})$ were mashed in a homogenizer and $4 \mathrm{~g}$ homogenate paste per sample were taken for extraction of vitamins $\mathrm{A}, \mathrm{E}, \beta$-carotene, and lycopene, and $1 \mathrm{~g}$ per sample was taken for extraction of vitamin C. To these homogenates, $4 \mathrm{~mL}$ of ethanol was added, vortexed, and the mixture centrifuged (Mistral \#2000) at $2000 \mathrm{rpm}$ for $3 \mathrm{~min}$ at $4 \mathrm{~h}$. The supernatant was also filtered through Whatman No. 1 paper and to the filtrate 0.15 $\mathrm{mL} n$-hexane was added and mixed. Vitamins $\mathrm{A}, \mathrm{E}$, and $\beta$-carotene were extracted twice in the hexane phase and the collected extract was dried under a stream of liquid nitrogen. Dried extract was solubilized in $0.2 \mathrm{~mL}$ methanol for HPLC. Injections were made in duplicate for each sample. The quantification (Catignani, 1983; Miller et al., 1984) used absorption spectra of 326, 296, and $436 \mathrm{~nm}$ for vitamins $\mathrm{A}, \mathrm{E}$, and $\beta$-carotene, respectively.

HPLC separations were accomplished at room temperature consisting of a sample injection valve (Cotati 7125 ) with a $20-\mathrm{mL}$ sample loop, an ultraviolet spectrophotometric detector [and a Techsphere ODS-2 packed (5-mm particle and $80 \mathrm{~A}^{\circ}$ pore size) column (250_4.6 i.d.) with a methanol:acetonitrile: chloroform $(47: 42: 11, \mathrm{v} / \mathrm{v})$ mobile phase at $1 \mathrm{~mL} \cdot \mathrm{min}^{-1}$ _flow rate]. The extraction of vitamin $\mathrm{C}$ was according to the method of Cerhata et al. (1994). To $1 \mathrm{~g}$ homogenized apricot paste, $1 \mathrm{~mL}$ of $0.5 \mathrm{M}$ perchloric acid was added, vortexed, and the volume adjusted to $5 \mathrm{~mL}$ by adding dd $\mathrm{H}_{2} \mathrm{O}$. The mixture was centrifuged at $5000 \mathrm{rpm}$ for $8 \mathrm{~min}$ at $4{ }^{\circ} \mathrm{C}$. The supernatant was filtered, as earlier, and the vitamin $\mathrm{C}$ level was determined using the method of Tavazzi et al. (1992) by HPLC using a column (250_3.9 i.d.) packed with Tecopak C18 reversed-phase material $(10 \mathrm{~mm}$ particle size) with mobile phase $(3.7 \mathrm{~mm}$ phosphate buffer, $\mathrm{pH} 4.0$ ) at $1 \mathrm{~mL} \cdot \mathrm{min}^{-1}$ flow rate. 


\section{Statistical analysis}

Experimental data were evaluated using analysis of variance and significant differences among the means $(P<0.05)$ were determined by Duncan's multiple range test using the SPSS 10.0 for Windows (SPSS Inc., Chicago, IL).

\section{Results and Discussion}

Vitamin levels (A, E, C, $\beta$-carotene, and lycopene) in fresh apricots at different stages of ripening are depicted in Table 2. Average vitamin levels per gram were measured in fresh apricots of all types. It has been determined that vitamin A level ranged between 25.5 and $2.04 \mu \mathrm{g} \cdot \mathrm{g}^{-1}$ dry matter; vitamin $\mathrm{E}$ level ranged between 65.33 and $25.33 \mu \mathrm{g} \cdot \mathrm{g}^{-1}$ dry matter; vitamin $\mathrm{C}$ level ranged between $18,553.51$ and $3,923.21 \mu \mathrm{g} \cdot \mathrm{g}^{-1}$ dry matter; $\beta$-carotene level ranged between 2100.00 and $171.42 \mu \mathrm{g} \cdot \mathrm{g}^{-1}$ dry matter; and lycopene level ranged between 70.0 and $8.32 \mu \mathrm{g} \cdot \mathrm{g}^{-1}$ dry matter.

With respect to ripening stages, in general, highest vitamin levels (A, E, $\beta$-carotene, and lycopene) were determined in early period apricots, whereas the highest vitamin C level was determined in late-period 'Levent' apricots. No lycopene content was determined in none of the late-period apricots. As seen from Table 2, vitamin levels (A, E, $\beta$-carotene, and lycopene) in early-period apricots are significantly higher (2.5 to three times) than those of middle- and late-period apricots $(P<0.05)$. Vitamin A, E, $\beta$-carotene, and lycopene levels in all early-period apricots were higher compared with those of middle- and late-period apricots and lowest vitamin levels were recorded in late-period apricots.

Early-period 'Boccucia' apricot demonstrated significantly higher levels of vitamin A $\left(25.51 \mu \mathrm{g} \cdot \mathrm{g}^{-1}\right.$ dry matter $), \beta$-carotene (2100.00 $\mu \mathrm{g} \cdot \mathrm{g}^{-1}$ dry matter), and lycopene (70.08 $\mu \mathrm{g} \cdot \mathrm{g}^{-1}$ dry matter) than all other apricots. On the other hand, the lowest levels of vitamin A (2.04 $\mu \mathrm{g} \cdot \mathrm{g}^{-1}$ dry matter) and $\beta$-carotene $\left(171.42 \mu \mathrm{g} \cdot \mathrm{g}^{-1}\right.$ dry matter) were determined in late-period 'Levent' apricot and the lowest level of vitamin E $\left(253,324.00 \mu \mathrm{g} \mathrm{g}^{-1}\right.$ dry matter) was recorded in pre-late-period 'Özal' apricot. The highest vitamin E level (65.33 $\mu \mathrm{g} \cdot \mathrm{g}^{-1}$ dry matter) was measured in early-period 'Tyrinte' apricot and the highest vitamin $\mathrm{C}$ level $\left(18,553.51 \mu \mathrm{g} \cdot \mathrm{g}^{-1}\right.$ dry matter) was measured in late-period 'Levent' apricot.

Differentials in percent values of the compounds in early-, middle-, and late-period apricots are compared in Table 2 as $\mu \mathrm{g} \cdot \mathrm{g}^{-1}$ dry matter. Generally, vitamin A, E, $\beta$-carotene, and lycopene levels in early-period apricots were higher compared with middle- and lateperiod apricot types and vitamin $C$ level was higher in late-period 'Levent' apricot. No statistically significant differences were identified between vitamin $\mathrm{C}$ levels of other apricot types $(P<005)$. Munzuroglu et al. (2003) have also formerly conducted a study on the determination of vitamin $\mathrm{A}, \mathrm{E}, \mathrm{C}$, and $\beta$-carotene levels in different apricot types.
Vitamin A, $\beta$-carotene, and lycopene levels in early-period 'Boccucia' and 'Dörtyol-4' apricots were found to be significantly higher $(P<005)$ compared with those of earlyperiod 'Tyrinte' and 'Ce De Rona' apricots as well as all middle- and late-period apricots. No statistically significant differences were determined between vitamin $\mathrm{E}$ levels of early-period 'Tyrinte' and 'Dörtyol-4' apricots. However, vitamin E levels in these apricots were significantly higher $(P<0.005)$ compared with those of other early-period apricot types 'Boccucia' and 'Ce De Rona' as well as middle- and late-period apricots. The significantly highest vitamin C level was measured in late-period 'Levent' apricot, whereas the lowest level was measured in 'Ce De rona', 'Geç aprikoz', 'Tyrinte', 'Özal', and 'Ziraat Okulu' apricots with no statistically significant differences in between $(P<$ $0.005)$. As indicated by the findings, harvest date, average temperature $\left({ }^{\circ} \mathrm{C}\right)$, total precipitation $(\mathrm{mm})$, antinographic insolation values $\left(\mathrm{CAL} / \mathrm{cm}^{2} / \mathrm{min}\right)$, average relative humidity (\%), average minimum-maximum temperature, and cultivar type are considered to be the determinants of vitamin A, E, $\beta$-carotene, and lycopene contents.

Dragovic-Uzelac et al. (2007) conducted a study on 'Keckemetska ruza', 'Madjarska najbolja', and 'Velika rana' apricots grown in Neretva valley and they determined $\beta$-carotene contents of these apricots in the ripeness stage, respectively, as $795.5 \mu \mathrm{g} / 100 \mathrm{~g}$, $1374.95 \mu \mathrm{g} / 100 \mathrm{~g}$, and $948.33 \mu \mathrm{g} / 100 \mathrm{~g}$. The findings of this study are partially in accord with the findings of other researchers and

Table 2. Vitamin A, E, C, lycopene, and $\beta$-carotene contents in apricot types and cultivars $\left(\mu g \cdot g^{-1}\right.$ dry matter).

\begin{tabular}{llccccc}
\hline \multirow{2}{*}{ Ripening time } & $\begin{array}{l}\text { Types and } \\
\text { cultivars }\end{array}$ & $\mathrm{A}$ & $\mathrm{E}$ & $\mathrm{C}$ & $\beta$-carotene & Lycopene \\
\hline Early ripening & Boccucia & $25.51 \mathrm{a}^{\mathrm{z}}$ & $41.73 \mathrm{e}$ & $9,122.32 \mathrm{ab}$ & $2,100.00 \mathrm{a}$ & $70.08 \mathrm{a}$ \\
& Dörtyol-4 & $16.00 \mathrm{~b}$ & $64.67 \mathrm{a}$ & $10,329.97 \mathrm{ab}$ & $1,567.50 \mathrm{~b}$ & $52.28 \mathrm{ab}$ \\
& C.D. Rona & $9.90 \mathrm{c}$ & $52.93 \mathrm{bc}$ & $7,799.62 \mathrm{~b}$ & $1,144.50 \mathrm{c}$ & $38.17 \mathrm{~cd}$ \\
& Tyrinte & $11.25 \mathrm{cb}$ & $65.33 \mathrm{a}$ & $6,855.43 \mathrm{~b}$ & $950.00 \mathrm{~d}$ & $31.48 \mathrm{cde}$ \\
Medium ripening & Adilcevaz & $10.73 \mathrm{c}$ & $46.00 \mathrm{de}$ & $8,960.48 \mathrm{ab}$ & $650.69 \mathrm{ef}$ & $21.69 \mathrm{def}$ \\
& Ordubat & $2.97 \mathrm{de}$ & $54.00 \mathrm{bc}$ & $9,740.84 \mathrm{ab}$ & $249.55 \mathrm{~g}$ & $8.32 \mathrm{ef}$ \\
& Ziraat okulu & $10.06 \mathrm{c}$ & $50.67 \mathrm{dc}$ & $3,923.21 \mathrm{~b}$ & $733.48 \mathrm{e}$ & $24.45 \mathrm{def}$ \\
& Aprikoz & $8.00 \mathrm{dc}$ & $60.00 \mathrm{ab}$ & $7,284.11 \mathrm{ab}$ & $750.97 \mathrm{e}$ & ND \\
& Geç Aprikoz & $7.40 \mathrm{dc}$ & $28.00 \mathrm{f}$ & $10,812.53 \mathrm{~b}$ & $621.53 \mathrm{ef}$ & ND \\
& Levent & $2.04 \mathrm{e}$ & $26.00 \mathrm{f}$ & $18,553.51 \mathrm{a}$ & $171.42 \mathrm{~g}$ & ND \\
& Özal & $6.24 \mathrm{cde}$ & $25.33 \mathrm{f}$ & $5,853.31 \mathrm{~b}$ & $523.58 \mathrm{f}$ & ND \\
\hline
\end{tabular}

${ }^{\mathrm{z}}$ Different letters in columns indicate significantly different values at $P \leq 0.05$.

$\mathrm{ND}=$ not determined.

Table 3. Polyphenol contents in early-, middle-, and late-period apricots $\left(\mu \mathrm{g} \cdot \mathrm{g}^{-1}\right.$ dry matter).

\begin{tabular}{llccccr}
\hline \multirow{2}{*}{ Ripening time } & $\begin{array}{l}\text { Types and } \\
\text { cultivars }\end{array}$ & Rutin & Ferulic acid & Catechin & $\begin{array}{c}\text { Chlorogenic } \\
\text { acid }\end{array}$ & Epicatechin \\
\hline Early ripening & Boccucia & $12,338.11 \mathrm{a}^{\mathrm{z}}$ & $577.77 \mathrm{e}$ & $812.55 \mathrm{de}$ & $2,245.53 \mathrm{~cd}$ & $514.65 \mathrm{~cd}$ \\
& Dörtyol-4 & $5,362.92 \mathrm{c}$ & $859.18 \mathrm{c}$ & $931.89 \mathrm{~d}$ & $1,364.93 \mathrm{~cd}$ & $340.49 \mathrm{de}$ \\
& C.D. Rona & $3,805.68 \mathrm{ed}$ & $771.27 \mathrm{~d}$ & $1523.53 \mathrm{c}$ & $525.77 \mathrm{~d}$ & $340.49 \mathrm{de}$ \\
\multirow{4}{*}{ Medium ripening } & Tyrinte & $13,262.42 \mathrm{a}$ & $246.55 \mathrm{e}$ & $1498.14 \mathrm{c}$ & $1,240.61 \mathrm{~cd}$ & $964.55 \mathrm{~b}$ \\
& Adilcevaz & $3,823.48 \mathrm{ed}$ & $1339.83 \mathrm{~b}$ & $2417.33 \mathrm{~b}$ & $782.18 \mathrm{~cd}$ & $1279.37 \mathrm{a}$ \\
& Ordubat & $5,142.76 \mathrm{c}$ & $433.33 \mathrm{f}$ & $837.94 \mathrm{ed}$ & $5,692.82 \mathrm{c}$ & $1234.72 \mathrm{a}$ \\
& Ziraat okulu & $3,145.23 \mathrm{e}$ & $191.01 \mathrm{e}$ & $372.24 \mathrm{f}$ & $2,545.97 \mathrm{~cd}$ & $292.49 \mathrm{f}$ \\
\multirow{2}{*}{ Late ripening } & Aprikoz & $9,812.86 \mathrm{~b}$ & $1576.41 \mathrm{a}$ & $3250.19 \mathrm{a}$ & $2,434.60 \mathrm{~cd}$ & $358.36 \mathrm{de}$ \\
& GeçAprikoz & $5,528.03 \mathrm{c}$ & $393.43 \mathrm{f}$ & $1371.18 \mathrm{c}$ & $31,598.00 \mathrm{~b}$ & $432.04 \mathrm{de}$ \\
& Levent & $4,890.24 \mathrm{dc}$ & $405.43 \mathrm{f}$ & $571.32 \mathrm{fed}$ & $1,427.09 \mathrm{~cd}$ & $85.96 \mathrm{~g}$ \\
& Özal & $3,501.35 \mathrm{e}$ & $786.96 \mathrm{dc}$ & $479.91 \mathrm{fe}$ & $45,843.00 \mathrm{a}$ & $624.06 \mathrm{c}$ \\
\hline
\end{tabular}

${ }^{z}$ Different letters in columns indicate significantly different values at $P \leq 0.05$. comparatively higher and lower findings are also observed in this study. Although all vitamin $\mathrm{C}$ analysis procedures were conducted by using ice, degradation was obdifferences in cultivars are attributed to cultivar and genotype characteristics, applied crop procedures, and environmental factors (Yilmaz et al.,

Phenolic acids and their derivatives (3-BQ-D, procyanidin B1, B2, B3, caffeic acid, gallic acid, p-coumaric acid, epigallocatechin, catechin, epicatechin, chlorogenic acid, ferulic and quercetin-3-rutunoside) were deterKan and Bostan (2013) also formerly determined some of these polyphenols (caffeic acid, gallic acid, p-coumaric acid, epigallocatechin, atechin, epicatechin, chlorogenic acid, ferulic conventionally grown cultivars and rutin was identified to be the dominant flavonol in all apricot types.

Statistically significant differences $(P<$ (rintied between quercetinquercetin-3-rutunoside (rutin) contents $\mu \mathrm{g} \cdot \mathrm{g}^{-1}$ in early-period 'Boccucia' and 'Tyrinte' apricots were equal and ranged between 12,338.11 $13,262.42 \mu \mathrm{g} \cdot \mathrm{g}^{-1}$ dry matter. Furthermore, no statistically significant differences $(P<$ of early-period 'Dörtyol-4' apricot, middleperiod 'Ordubat' apricot, and late-period 'Levent' apricot. The lowest level of p-coumaric acid $\left(7.929 \mu \mathrm{g} \cdot \mathrm{g}^{-1}\right.$ dry matter) was measured 
Table 4. Polyphenol contents in early-, middle- and late-period apricots $\left(\mu \mathrm{g} \cdot \mathrm{g}^{-1}\right.$ dry matter).

\begin{tabular}{llcrrr}
\hline Ripening time & Types and cultivars & Epigalocatechin & 3-BQ-D & P-qumaric acid & Gallic acid \\
\hline Early ripening & Boccucia & $205.41 \mathrm{~cd}^{\mathrm{z}}$ & $380.88 \mathrm{c}$ & $12.30 \mathrm{e}$ & $880.50 \mathrm{~d}$ \\
& Dörtyol-4 & $220.86 \mathrm{c}$ & $205.67 \mathrm{e}$ & $52.62 \mathrm{c}$ & $548.00 \mathrm{e}$ \\
& C.D. Rona & $426.90 \mathrm{a}$ & $421.82 \mathrm{~b}$ & $12.01 \mathrm{e}$ & $1268.02 \mathrm{~b}$ \\
& Tyrinte & $361.71 \mathrm{~b}$ & $445.54 \mathrm{a}$ & $81.93 \mathrm{~b}$ & $1052.00 \mathrm{c}$ \\
Medium ripening & Adilcevaz & $85.52 \mathrm{e}$ & $61.23 \mathrm{~h}$ & $7.93 \mathrm{e}$ & $1875.00 \mathrm{a}$ \\
& Ordubat & $91.81 \mathrm{e}$ & $110.46 \mathrm{~g}$ & $129.3 \mathrm{a}$ & $614.50 \mathrm{e}$ \\
& Ziraat okulu & $81.00 \mathrm{e}$ & $165.65 \mathrm{f}$ & $14.49 \mathrm{e}$ & $635.00 \mathrm{e}$ \\
Late ripening & Aprikoz & $225.96 \mathrm{c}$ & $265.67 \mathrm{~d}$ & $79.45 \mathrm{~b}$ & $868.25 \mathrm{~d}$ \\
& Geç Aprikoz & $74.48 \mathrm{ef}$ & $199.01 \mathrm{e}$ & $19.39 \mathrm{e}$ & $485.25 \mathrm{f}$ \\
& Levent & $45.91 \mathrm{f}$ & $188.73 \mathrm{e}$ & $33.40 \mathrm{~d}$ & $512.60 \mathrm{f}$ \\
& Özal & $181.32 \mathrm{~d}$ & $52.28 \mathrm{~h}$ & $19.44 \mathrm{e}$ & $365.00 \mathrm{~g}$ \\
\hline
\end{tabular}

${ }^{\mathrm{z}}$ Different letters in columns indicate significantly different values at $P \leq 0.05$.

Table 5. Polyphenol contents in early-, middle-, and late-period apricots $\left(\mu \mathrm{g} \cdot \mathrm{g}^{-1}\right.$ dry matter).

\begin{tabular}{lllccc}
\hline \multirow{2}{*}{ Ripening time } & $\begin{array}{c}\text { Types and } \\
\text { cultivars }\end{array}$ & Caffeic acid & Procyanidin B1 & Procyanidin B2 & Procyanidin B3 \\
\hline Early ripening & Boccucia & $979.05 \mathrm{a}^{\mathrm{z}}$ & $485.39 \mathrm{~b}$ & $416.65 \mathrm{~d}$ & $422.86 \mathrm{ef}$ \\
& Dörtyol-4 & $394.76 \mathrm{~cd}$ & $375.04 \mathrm{c}$ & $445.37 \mathrm{~d}$ & $642.21 \mathrm{~b}$ \\
& C.D. Rona & $413.24 \mathrm{c}$ & $521.41 \mathrm{~b}$ & $914.01 \mathrm{~b}$ & $875.14 \mathrm{a}$ \\
\multirow{5}{*}{ Medium ripening } & Tyrinte & $656.23 \mathrm{~b}$ & $1069.37 \mathrm{a}$ & $639.99 \mathrm{c}$ & $568.21 \mathrm{c}$ \\
& Adilcevaz & $317.20 \mathrm{cde}$ & $125.90 \mathrm{e}$ & $402.58 \mathrm{de}$ & $475.71 \mathrm{ef}$ \\
& Ordubat & $213.89 \mathrm{ef}$ & $381.11 \mathrm{c}$ & $227.09 \mathrm{f}$ & $406.21 \mathrm{ef}$ \\
\multirow{4}{*}{ Late ripening } & Ziraat okulu & $212.15 \mathrm{ef}$ & $86.46 \mathrm{e}$ & $304.04 \mathrm{ef}$ & $179.45 \mathrm{~h}$ \\
& Aprikoz & $270.64 \mathrm{de}$ & $1071.27 \mathrm{a}$ & $446.68 \mathrm{~d}$ & $562.93 \mathrm{c}$ \\
& Geç Aprikoz & $283.74 \mathrm{de}$ & $182.21 \mathrm{~d}$ & $1039.75 \mathrm{a}$ & $298.64 \mathrm{~g}$ \\
& Levent & $100.98 \mathrm{f}$ & $483.11 \mathrm{~b}$ & $728.20 \mathrm{c}$ & $388.50 \mathrm{f}$ \\
& Özal & $667.87 \mathrm{~b}$ & $111.11 \mathrm{e}$ & $433.54 \mathrm{~d}$ & $528.57 \mathrm{dc}$ \\
\hline
\end{tabular}

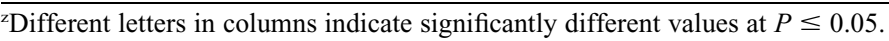

in 'Adilcevaz', 'C.D. Rona', 'Boccucia', and 'Ordubat', respectively.

Ferulic acid and catechin levels in early-, middle-, and late-period apricots varied significantly $(P<0.05)$. The highest ferulic acid and catechin levels were determined in middle-period 'Aprikoz' and 'Adilcevaz' apricots, whereas the lowest ferulic acid and catechin levels were measured in middle-period 'Ziraat okulu' apricot.

Levels of chlorogenic acid were also found to vary significantly $(P<0.05)$. The highest level of chlorogenic acid $(31,598.0$ to $45,843.00 \mu \mathrm{g} \cdot \mathrm{g}^{-1}$ dry matter) was determined in late-period 'Levent' and 'Özal' apricots, whereas the lowest chlorogenic acid content (525.77 $\mu \mathrm{g} \cdot \mathrm{g}^{-1}$ dry matter) was measured in early-period 'Ce De Rona' apricot. Levels of epicatechin were also found to vary significantly $(P<0.05)$. Although the highest epicatechin levels (1279.37 to $1234.72 \mu \mathrm{g} \cdot \mathrm{g}^{-1}$ dry matter) were measured in middle-period 'Adil cevaz' and 'Ordubat' apricots, the lowest epicatechin level $\left(433.327 \mu \mathrm{g} \cdot \mathrm{g}^{-1}\right.$ dry matter) was recorded in late-period ' $\mathrm{Gec}$ aprikoz' apricot.

The highest epigallocatechin levels (426.903 to $361.71 \mu \mathrm{g} \cdot \mathrm{g}^{-1}$ dry matter) were determined in early-period 'Ce De Rona' and 'Tyrinte' apricots, whereas the lowest epigallocatechin level $\left(45.91 \mu \mathrm{g} \cdot \mathrm{g}^{-1}\right.$ dry matter) was measured in late-period 'Geç aprikoz' apricot. Epigallocatechin and 3-B-Q-D levels were found to vary significantly $(P<0.05)$.

Levels of gallic acid were also found to vary significantly $(P<0.05)$. The highest $\left(1875.00 \_\mu \mathrm{g} \cdot \mathrm{g}^{-1}\right.$ dry matter) and the lowest (365.00 $\mu \mathrm{g} \cdot \mathrm{g}^{-1}$ dry matter) gallic acid levels were measured in middle-period 'Adil cevaz' apricot and late-period 'Özal' apricot, respectively.

The highest procyanidin B1 levels (1071.27 to $1069.37 \mu \mathrm{g} \cdot \mathrm{g}^{-1}$ dry matter) were measured in middle-period 'Aprikoz' apricot and early-period 'Tyrinte' apricot. The lowest procyanidin B1 levels (125.90 to $86.46 \mu \mathrm{g} \cdot \mathrm{g}^{-1}$ dry matter) were measured in late-period 'Özal' apricot and middle-period 'Adilcevaz' and 'Ziraat okulu' apricots. Provitamin B1 levels were found to vary significantly $(P<$ $0.05)$. Procyanidin B2 levels were also found to vary significantly $(P<0.05)$. The highest procyanidin B2 level $\left(1039.75 \mu \mathrm{g} \cdot \mathrm{g}^{-1}\right.$ dry matter) was determined in late-period 'Levent' apricot, whereas the lowest procyanidin B2 level (227.09 $\mu \mathrm{g} \cdot \mathrm{g}^{-1}$ dry matter) was measured in middle-period 'Ordubat' apricot. Procyanidin B3 levels were also found to vary significantly $(P<0.05)$. The highest procyanidin B3 level $\left(875.14 \mu \mathrm{g} \cdot \mathrm{g}^{-1}\right.$ dry matter) was measured in early-period ' $\mathrm{Ce}$ De Rona' apricot and the lowest procyanidin

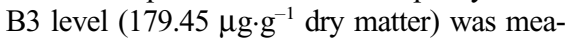
sured in middle-period 'Ziraat okulu' apricot.

Levels of caffeic acid were also found to vary significantly $(P<0.05)$. The highest $\left(979.05 \mu \mathrm{g} \cdot \mathrm{g}^{-1}\right.$ dry matter) and the lowest (100.98 $\mu \mathrm{g} \cdot \mathrm{g}^{-1}$ dry matter) levels of caffeic acid were measured in early-period 'Boccucia' apricot and late-period 'Levent' apricot, respectively. The highest levels of quercetin-3rutinoside (rutin) were measured in earlyperiod 'Tyrinte' and 'Boccucia' apricots; the highest levels of ferulic acid and catechin were measured in middle-period 'Aprikoz' apricot; the highest levels of epicatechin were measured in middle-period 'Adilcevaz' and 'Ordubat' apricots; the highest level of chlorogenic acid was measured in late-period 'Özal' apricot; the highest level of epigallocatechin was measured in early-period 'Ce De Rona' apricot; the highest level of 3-B-Q-D was measured in early-period 'Tyrinte' apricot; the highest level of p-coumaric acid was measured in middle-period 'Ordubat' apricot; the highest level of gallic acid was measured in middle-period 'Adil cevaz' apricot; the highest levels of provitamin B1 were measured in middle-period 'Aprikoz' apricot and earlyperiod 'Tyrinte' apricot; the highest level of caffeic acid was measured in early-period 'Boccucia' apricot; the highest level of provitamin B2 was measured in late-period 'Levent' apricot; and the highest level of procyanidin B3 was measured in early-period 'Ce De Rona' apricot.

Cultivar type was observed to be the predominant determinant of the polyphenol levels depicted previously and ripening stage (early, middle, and late period) was not identified to be effective on polyphenol levels. Cultivar type, ripening stage, and exposure to sunlight were observed to be the determinants of vitamin A, E, C, $\beta$-carotene, and lycopene levels. Biochemical changes associated with different ripening stages in apricots are examined in a very limited number of studies. (Sharaf et al., 1989). There is not any reliable and precise data on carotenoids during the ripening period of apricots. The findings indicate that carotene and vitamin production is insufficient in late-period apricots as a result of incomplete ripening and inadequate exposure to sunlight. No lycopene content was determined in lateperiod apricots in our study. The studies on different plant species report significant changes in carotenoid levels throughout the ripening period. Apricots are rich in carotenoids. Particularly $\beta$-carotene represents more than $50 \%$ of the total carotenoid content in apricots (Radi et al., 1997).

\section{Conclusion}

During ripening, carotenoid concentration increases, chlorophyll concentration decreases, and organoleptical quality of the fruit undergoes changes (Burns et al., 2003). In early periods, the tomato fruits are green and contain the same elements of carotenoids (pcarotene, lutein, violaxanthin) as in green leaves. Other factors like smoke, dust, clouds, and rain might interfere with the sunlight effect and, hence, may indirectly affect red color formation (Andris and Crisosto, 1996).

Significantly higher levels of vitamin A, $\mathrm{E}, \beta$-carotene, and lycopene were determined in early-period apricots compared with those of middle- and late-period apricots and sunlight was identified to be an important determinant of the level of these nutrients. Fruit pomology was also found to be effective on the level of these nutrients. Early-period 'Boccucia' apricot was richer in phytochemicals compared with other apricot types and the lowest phytochemical content was 
identified in late-period 'Levent' apricot. A significant remark was the lack of lycopene production in all late-period apricots. On the other hand, late-period apricots contained significantly higher levels of vitamin $\mathrm{C}$ compared with those of early- and middle-period apricots. As known, the most important factors contributing to degradation of vitamin $\mathrm{C}$ are oxygen $\left(\mathrm{O}_{2}\right)$, exposure of the plant to sunlight, degradations in hormone concentration, and temperature. Additionally, cooler temperatures in fall as a result of shorter days and reduced exposure to sunlight lead to a decrease in respiration rate of the fruit and, hence, in amount of $\mathrm{O}_{2}$ concentration. These factors result a delay in degradation of vitamin C (Çelik et al., 2006) As seen from the findings on phenolic acids and flavonoids, apricot type is the predominant determinant of polyphenol levels.

In this study, chemical compounds of the apricot cultivars were examined throughout the ripening period and nutritional values and importance of these cultivars for human health were determined. In literature, there is a gap on studies examining the changes in carotenoid, vitamin, and polyphenol levels in apricots at different ripening stages (early, middle, and late periods). In this respect, this study is deemed valuable as a result of its contribution to the literature and guidance for forthcoming studies.

\section{Literature Cited}

Ali, S., T. Mesud, and K.S. Abbasi. 2011. Physicochemical characteristics of apricot (Prunus armeniaca L.) grown in northern areas of Pakistan. Sci. Hort. 130:386-392.

Altindag, M., M. Sahin, A. Esitken, S. Ercisli, and M. Guleryuz. 2006. Biological control of brown rot (Moniliana laxa Ehr.) on apricot (Prunus armeniaca L. cv. Hacihaliloglu) by Bacillus, Burkholdria, and Pseudomonas application under in vitro and in vivo conditions. Biol. Control 38:369-372.

Andris, H. and C.H. Crisosto. 1996. Reflective materials enhance 'Fuji' apple color. Calif. Agr. 50:27-30.

Arts, C.W. and B.P.C.H. van de Putte. 2000. HollmanCatechin contents of foods commonly consumed in the Netherlands. 1. Fruits, vegetables, staple foods and processed foods. J. Agr. Food Chem. 48:1746-1751.

Bengoechea, M.L., A.I.B. Sancho, I.E. Bartolomé, and G. Gómez-Cordovés. 2007. Phenolic composition of industrially manufactured purées and concentrates from peach and apple fruits. J. Agr. Food Chem. 45:4071-4075.

Burns, J., P.D. Fraser, and P.M. Bramley. 2003. Identification and quantification of carotenoids, tocopherols and chlorophylls in commonly consumed fruits and vegetables. Phytochem. 62:939-947.

Catignani, G.L. 1983. Simultaneous determination of retinol and a-tocopherol in serum or plasma by liquid chromatography. Clin. Chem. 2914: 708-712.
Çelik, F., A. Kazankaya, A. Doğan, H.İ. Oğuz, and A. Ekincialp. 2006. Kuşburnu Tiplerinde C Vitamini İçeriğine Farklı Rakımların Etkileri. II. Ulusal üzümsü meyveler sempozyumu Bildirileri, 14-16 Eylül 2006, Tokat, 313-316.

Cemeroğlu, B., A. Yemenicioglu, and M. Özkan. 2004. Meyve ve Sebzelerin Bileşimi. B. Cemeroğlu (eds.). 1. Meyve ve Sebze İşleme Teknolojisi, 2. Başkent Klişe Matbaacılık, vol. 1,670 .

Cerhata, D., A. Bauerova, and E. Ginter. 1994. Determination of ascorbic acid in blood serum using high performance liquid chromatography and its correlation with spectrophotometric. Caska-Slov-Farm. 434:166-168.

Criqui, M.H. and B.L. Ringel. 1994. Does diet or alcohol explain the French paradox. Lancet 344:1719-1723.

Dragovic-Uzelac, V., B. Levaj, V. Mrkic, D. Bursac, and M. Boras. 2007. The content of polyphenols and carotenoids in three apricot cultivars depending on stage of maturity and geographical region. Food Chem. 102:966-975.

Dragovic-Uzelac, V., J. Pospisil, B. Levaj, and K. Delonga. 2005a. The study of phenolic profiles of raw apricots and apples and their purees by HPLC for the evaluation of apricot nectars and jams authenticity. Food Chem. 91:373-383.

Dragovic-Uzelac, V., K. Delonga, B. Levaj, S. Djakovic, and J. Pospisil. 2005b. Phenolic profiles of raw apricots pumpkins and their purees in the evaluation of apricot nectars and jams authenticity. J. Agr. Food Chem. 53:4836-4842.

Ercisli, S. 2009. Apricot culture in Turkey. Sci. Res. and Ess. 4:715-719.

Erdoğan, S. and S. Erdemoğlu. 2011. Evaluation of polyphenol contents in differently processed apricots using accelerated solvent extraction followed by high-performance liquid chromatography-diode array detector. Intl. J. Food Sci. Nutr. 62:729-739.

Fraser, P.D. and P.M. Bramley. 2004. The biosynthesis and nutritional uses of carotenoids. Lipid Res. 43:228-265.

Fraser, P.D., M.R. Truesdale, C.R. Bird, W Schuch, and P.M. Bramley. 1994. Carotenoid biosynthesis during tomato fruit development. Plant Physiol. 105:405-413.

Garcia-Viguera, C., P. Zafrilla, and F.A. TomasBarberan. 1997. Determination of authenticity of fruit jams by HPLC analysis of anthocyanins. J. Sci. Food Agr. 73:207-213.

Gardner, T.A., D.B. White, G. McPhail, and G. Duthie. 2000. The relative contributions of vitamin $\mathrm{C}$, carotenoids and phenolics to the antioxidant potential of fruit juices. Food Chem. 68:471-474.

Gündogdu, M., F. Muradoglu, R.I. Gazioglu Sensoy, and H. Yilmaz. 2011. Determination of fruit chemical properties of Morus nigra L., Morus $a l b a \mathrm{~L}$. and Morus rubra L. by HPLC. Sci. Hort. 132:37-41.

Harris, R.S. 1977. Effects of agricultural practices on the composition of foods, p. 33-57. In: Harris, R.S. and E. Karmas (eds.). Nutritional evaluation of food processing. The Avi Publishing Company Inc., Westport, CT.

Henning, W. and K. Herrmann. 1980. Flavonol glycosides of apricots (Prunus armeniaca L.) and peaches (Prunus persica Batsch). Zetchrift für Lebensmmitel Untersuchung und. Forsc. 171:183-188.

Kan, T., and S.Z. Bostan. 2013. Effect of sulfurization and process condition on polyphenol content of Anatolian apricots (Prunus armeniaca). J. Food Proc. and Preser. 37:163-170.

Lee, S.K. and A.A. Kader. 2000. Preharvest and postharvest factors influencing vitamin $\mathrm{C}$ content of horticultural crops. Post. Bio. \& Tech. 20:207-220.

Lima, V.L.A.G., E.A. Mélo, M.I.S. Maciel, F.G. Prazeres, R.S. Musser, and D.E.S. Lima. 2005. Total phenolic and carotenoid contents in acerola genotypes harvested at three ripening stages. Food Chem. 90:565-568.

Macheix, J.J., A. Fleuriet, and J. Billot. 1990. Fruit phenolics. CRC Press, Boca Raton, FL. 24 31:295-342.

Miller, K.W., N.A. Lorr, and C.S. Yang. 1984. Simultaneous determination of plasma retinol a-tocopherol, lycopene, a-carotene, and bcarotene by high performance liquid chromatography. Anal. Biochem. 138:340-345.

Munzuroglu, O., F. Karatas, and H. Geckil. 2003. The vitamin and selenium contents of apricot fruit of different varieties cultivated in different geographical regions. Food Chem. 83:205212.

Radi, M., M. Mahrouz, and A. Jaouad. 1997. Phenolic content, browning susceptibility, and carotenoid content of several apricot cultivars at maturity. HortScience 32:1087-1091.

Renaud, S. and M. de Lorgeril. 1992. Wine, alcohol, platelets, and the French paradox for coronary heart disease. Lancet 339:15231526.

Rice-Evans, C.A., N.J. Miller, and G. Paganga. 1997. Antioxidant properties of phenolic compounds. Trends Plant Sci. 2:152-159.

Rish, B. and K. Herrmann Die Gehalte. 1988. Hydroxyzimtsare-verbindungen und Catechinen in Kern und Steinobst Zeitschrift für Lebensmmitel Untersuchung und. Forsch. 186: 225-230.

Sharaf, A., F.A. Ahmed, and S.S. El-Saadany. 1989. Biochemical changes in some fruits at different ripening stages. Food Chem. 31:1928.

Spanos, G.A. and R.E. Wrolstad. 1992. Phenolics of apple, pear and white grape juices and their changes with processing and storageA review. J. Agr. Food Chem. 40:1478 1487.

Speirs, J. and C.J. Brady. 1991. Modification of gene expression in ripening fruit. Austral. J. Plant Physiol. 18:519-532.

Tavazzi, B., G. Lazzarino, D. Di-Pierro, and B. Giardina. 1992. Malondialdehyde production and ascorbate decrease are associated to the perfusion of the isolated postischemic rat heart. Free Radic. Biol. Med. 13:75-78.

Vinson, J.A., Y. Hao, X. Su, and L. Zubik. 1998. Phenol antioxidant quantity and quality in foods. Vegetables. J. Agr. and Food Chem. 46:3630-3634.

Yilmaz, K.U., S. Ercisli, Y. Zengin, M. Sengul, and E.Y. Kafkas. 2009. Preliminary characterization of cornelian cherry (Cornus mas L.) genotypes for their physico-chemical properties. Food Chem. 114:408-412. 